\title{
Were the Marsupials the Key Sylvatic Reservoir of Leishmania?
}

\author{
João Carlos Araujo Carreira \\ Fundação Oswaldo Cruz \& Instituto Oswaldo Cruz/Instituto Nacional de Endemias Rurais Brasil (IOC/INERU), Brasil
}

Submission: November 07, 2017; Published: November 30, 2017

*Corresponding author: João Carlos Araujo Carreira, Fundação Oswaldo Cruz, Instituto Oswaldo Cruz/Instituto Nacional de Endemias Rurais Brasil (IOC/INERU), Av Brasil 4365, Manguinhos, RJ, Brasil, Email: carreira@ioc.fiocruz.br

Keywords: Leishmania; Marsupials; Co-evolution

\section{Editorial}

Rodents have been classically considered as the most important mammal hosts of cutaneous Leishmania probably because they are in general very susceptible to the parasite infections and consequently present a great number of reports of animals naturally infected with skin lesions [1]. Another factor that could seemingly favor the importance of rodents is that currently there is no marsupials in the Old World.

Nonetheless, if we take into account the evolutionary history, biogeography and infection patters in relation to the probable role on the co-evolution with the parasite. In this case, the marsupials mostly prevail.

In respect to the evolution, most studies related to rodents recognize a post-Cretaceous origin (after 65Myr) [2]. Moreover, in South America the oldest rodent fossil record has been dated still later during middle Eocene (41Myr) [3].

On the other hand, the origin and evolution of marsupials occurred quite before, the most ancient fossil record proving the marsupial origin was discovered in Jurassic deposits, dated with about 160Myr in China [4]. Furthermore, the earliest known metatherian fossil, the opossum-like Sinodelphys szalayi, comes from the early Cretaceous Yixian Formation (125Myr) also from China [5].

Concerning the biogeographic records of marsupials, the majority of paleontologists accept that Metatheria originated in Asia, in the Jurassic. Then diversified throughout the northern continents and dispersed into Gondwana (the modern Southern Hemisphere) around the beginning of the Paleocene epoch (65 million years ago) [6]. Finally, they moved through Antarctica to Australia, before the Australian continent was isolated (37Myr) by the opening of Drake Passage between South America and Antarctica [7].
Thus, when the rodents were taking the first steps in their evolution, the opossum-like marsupials were already widely dispersed in the most part of the world where Leishmania currently occurs. Regarding the infections patterns, as above mentioned most rodents are very susceptible, commonly presenting tissue lesions and because of that they are typically used to the parasite isolation in laboratory. Otherwise, the marsupials are frequently asymptomatic, presenting scarce lesions [1].

Likewise, if we consider the infection of didelphid marsupials with some trypanosomes that are highly pathogenic to rodents [8], such as, Trypanosoma cruzi or Trypanosoma evansi. Under natural conditions the infections in didelphids are constantly sub-patent and symptomless $[9,10]$ supporting the theory that marsupials and trypanosomatids probably have a very ancient co-evolutionary history.

Actually, the hypotheses about the arising of the mammals' Leishmania are controversial; while some authors have considered a Neotropical origin, others have suggested the probable emergence of the genus, either in the Palearctic or in the Nearctic region [11-13].

In the Neotropical origin, Noyes [11] proposed that a clade named Leishmania/Endotrypanum evolved in the Neotropics during the first half of the Cenozoic (65-40mya) and descendants of these parasites migrated through the Nearctic to the Palearctic no later than the mind-Miocene. Nevertheless, besides the opposite arguments reported by Kerr [12], posterior studies demonstrated that the stock of Endotrypanum (a sloth trypanosomatid) that was utilized to determine that clade, in fact was Leishmania. Therefore, the supposed clade EndotrypanumLeishmania, it actually does not exist. 
Probably the sloth from where the parasite was isolated had a mixt infection and at the laboratory, the Endotrypanum was lost, leaving only the Leishmania.

In the Palearctic origin, Kerr [12] based their theory on the fossil record and systematics of murid rodents. They also considered that the evolutionary pattern of New World rats (Sigmodontinae) indicates that they may be the most important reservoirs of zoonotic cutaneous leishmaniasis throughout their range.

Nevertheless, as already mentioned above, if we consider all the rodent groups, even those extinct, they present a very late evolutionary history, principally if we take into account their presence in South America [2,3].

In another theory about the evolution of Leishmania, Momem \& Cupolillo [14] suggested that this genus appeared during the period Paleogene or Paleocene, following the extinction of the dinosaurs and the emergence of the first placental mammals. Consequently, the ancestors of Leishmania were separated into Sauroleishmania, infecting reptiles such as lizards, in addition of the Leishmania of mammals.

Perrotey et al. [15] suggested that the dissemination of the parasite went along with the migration of vectors and hosts together, and that the natural hosts of ancient Leishmania could have been either reptiles or primitive mammals [15].

More recently, Tuon et al. [16] supposedly based on geological evidences related to the separation of the continents in addition to the probable occurrence of hosts and vectors as well as molecular parameters; they proposed the origin of Leishmania could be occurred during one of the four ensuing geological periods: Triassic, Jurassic, Cretaceous and Neogene.

A common point of all the hypotheses proposed by Tuon et al. [16], consists of assuming that the origin of Leishmania occurred in Central Africa, consequently if it is currently thought that the first mammals emerged in Asia [4] during the Jurassic period (based in fossil records), consequently this aspect could represent an incongruence.

Anyway, based on the assertion that mammal Leishmania evolved from reptile parasites to primitive mammals and considering the above information related to the origin, biogeography and infection profiles in marsupials, we are proposing that those animals have had a key role on the evolution of Leishmania principally in the New World.

So, we presumed that the Leishmania of mammals originated in Asia at the Jurassic period infecting primitive marsupials, then they diversified throughout the northern continents following their Hosts and dispersed into Gondwana (the modern Southern Hemisphere) in the course of the Paleocene epoch (65 million years ago). It is probable that the first species of the subgenus Leishmania (Leishmania) have emerged during this time (Figure $1 \& 2)$.

In the mean time in the Cretaceous, around 105Myr, when South America started splitting apart from Africa, probably the first species of the subgenus Leishmania (Viannia) could have emerged and diversified during more than sixty millions of years while South American was an island continent (Figure 2) [7].

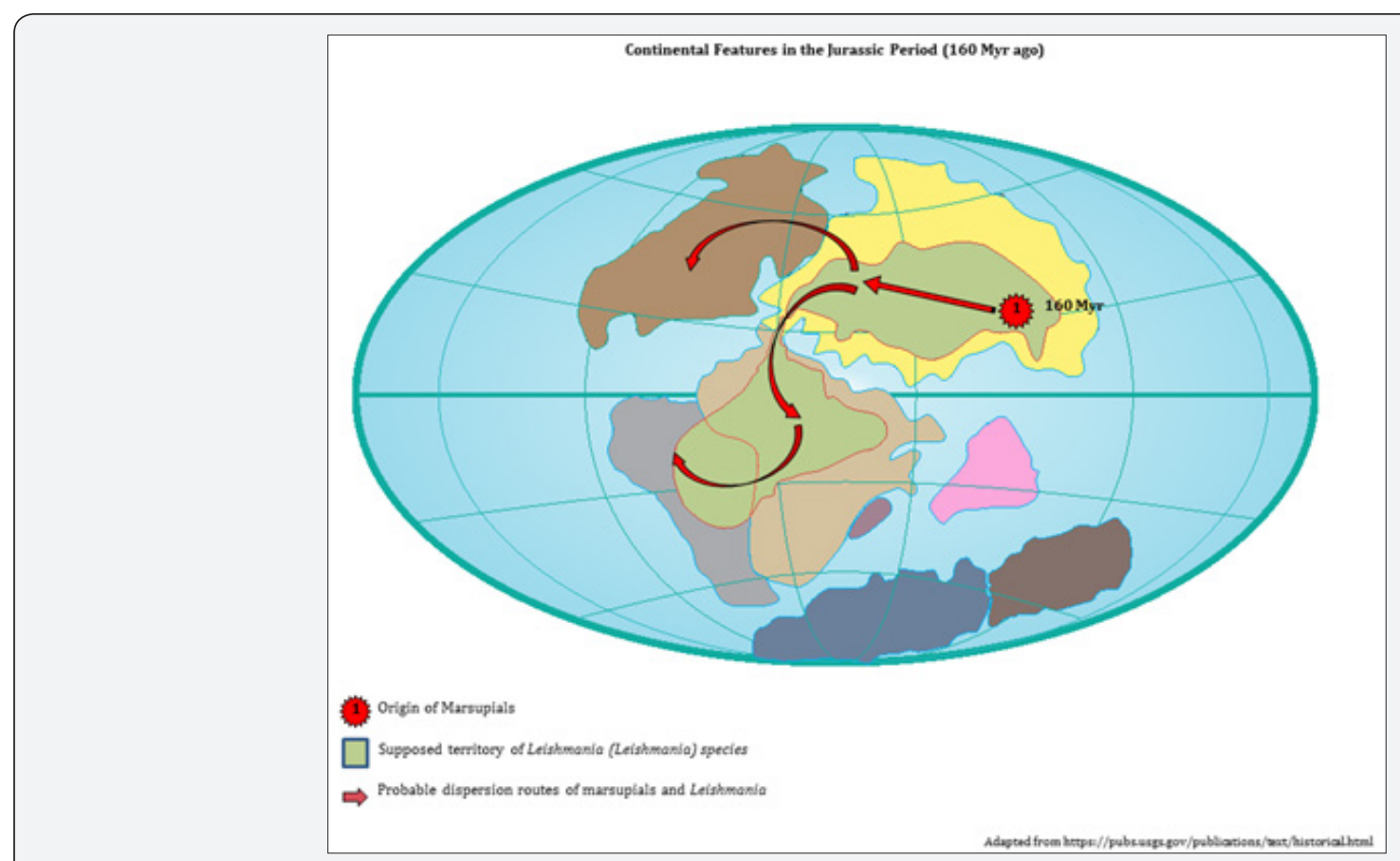

Figure 1: Continental features in the Jurassic period (160 Myr Ago). 


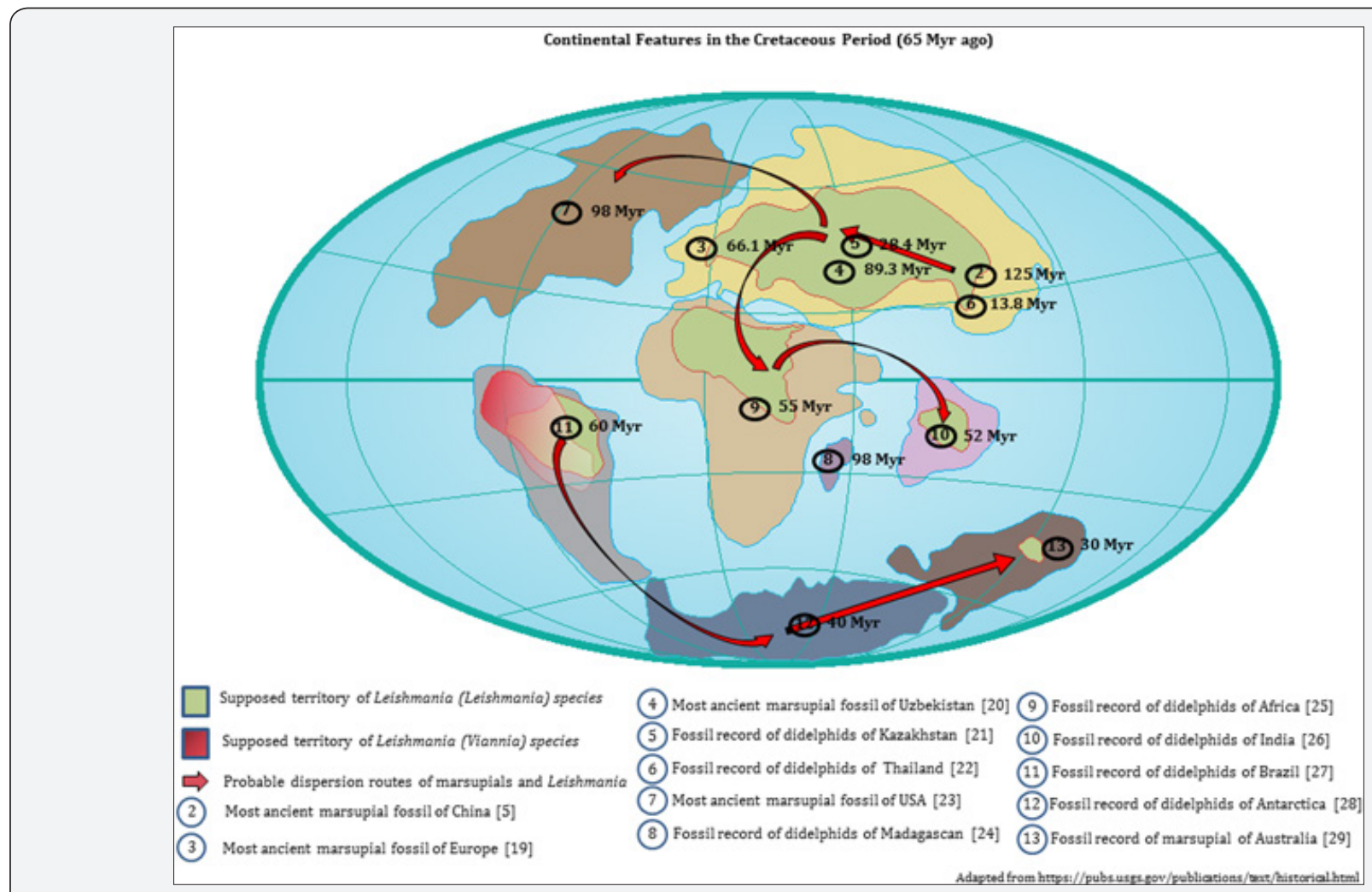

Figure 2: Continental features in the Cretaceous period (65 Myr Ago).

Likewise, it is probable that some parasite species could even have followed their marsupial host moving through Antarctica to Australia before the Australian continent was isolated by the opening of Drake Passage between South America and Antarctica. Because it was already observed the existence of a close molecular relationship between a kangaroo Leishmania species and Leishmania enriettii, an enigmatic parasite species isolated from domestic guinea pigs in Brazil where potential vectors were also associated to opossum nests, but nobody knows its natural host until now [17].

Finally, some Leishmania species could have reached the Central and North American Continents quite after, when occurred the Great American Biotic Interchange that started in late Miocene ( 10-7Ma) [18], rapidly increased after $\sim 5 \mathrm{Ma}$ and during the Pleistocene [19-29].

\section{References}

1. Carreira JCA, Magalhães MAFM, Brazil RP, Silva AVM (2017) Leishmania in marsupials - An overview of infection records in the americas and australia. OJAS 7(3): 315-343.

2. Wu S, Wu W, Zhang F, Ye J, Ni X, et al. (2012) Molecular and paleontological evidence for a post-cretaceous origin of rodents. PLoS One 7(10): e46445.

3. Antoine PO, Marivaux L, Croft DA, Billet G, Ganerod M, et al. (2012) Middle Eocene rodents from peruvian amazonia reveal the pattern and timing of caviomorph origins and biogeography. Proc Biol Sci 279(1732): 1319-1326.

4. Luo ZX, Yuan CX, Meng QJ, Ji Q (2011) A Jurassic eutherian mammal and divergence of marsupials and placentals. Nature 476: 442-445.
5. Luo ZX, Ji Q, Wible JR, Yuan CX (2003) An Early Cretaceous tribosphenic mammal and metatherian evolution. Science 302 (5652): 1934-1940.

6. Bennett V (2012) Fossil Focus: Marsupial evolution-A limited story? Palaeontology Online 2: 1-9.

7. Exon N, Kennett J, Malone M, Brinkhuis H, Chaproniere G, et al (2002) Drilling reveals climatic consequences of Tasmanian gateway opening. EOS Transactions American Geophysical Union 83(23): 253-264.

8. Biswas D, Choudhury A, Misra KK (2001) Histopathology of Trypanosoma (Trypanozoon) evansi infection in Bandicoot rat I. visceral organs. Exp Parasitol 99(3): 148-159.

9. Carreira JCA, Jansen AM, Lenzi HL (1996) Histopathological study of $D$. marsupialis: natural and experimental infections by T. cruzi. Mem Inst Oswaldo Cruz 91: 609-618.

10. Herrera HM, Dávila AM, Noreka A, Abreu UG, Souza SS, et al. (2004) Enzootiology of trypanosoma evansi in pantanal, Brazil. Vet Parasitol 125(3-4): 263-275.

11. Noyes H (1998) Implications of a Neotropical origin of the genus Leishmania. Mem Inst Oswaldo Cruz 93(5): 657-661.

12. Kerr SF (2000) Palaearctic origin of Leishmania. Mem Inst Oswaldo Cruz 95(1): 75-80.

13. Lukes J, Mauricio IL, Schonian G, Dujardin JC, Soteriadou K, et al. (2007) Evolutionary and geographical history of the Leishmania donovani complex with a revision of current taxonomy. Proc Natl Acad Sci USA 104(22): 9375-9380.

14. Momem H, Cupolillo E (2000) Speculations on the origin and evolution of the genus Leishmania. Mem Inst Oswaldo Cruz 95(4): 583-588.

15. Perrotey S, Mahamdallie SS, Pesson B, Richardson KJ, Gallego M, et al. (2005) Postglacial dispersal of Phlebotomus perniciosus into France. Parasite 12(4): 283-291. 
16. Tuon FF, Neto VA, Amato VS (2008) Leishmania: origin, evolution and future since the Precambrian. FEMS Immunol Med Microbiol 54(2): 158-166.

17. Lainson R (1997) On Leishmania enrietti and other enigmatic Leishmania species of the Neotropics. Mem Inst Oswaldo Cruz 92(3): 377-387.

18. Carrillo JD, Forasiepi A, Jaramillo C, Sánchez-Villagra MR (2015) Neotropical mammal diversity and the Great American Biotic Interchange: spatial and temporal variation in South America's fossil record. Front Genet 5: 451 .

19. Martin JE, Case JA, Jagt JWM, Schulp AS, Mulder EWA (2005) A new europe marsupial indicates a Late Cretaceous high-latitude transatlantic dispersal route. J Mammal Evolution 12(3-4): 495-511.

20. Averianov A, Jaworowska K (1999) Marsupials from the Late Cretaceous of Uzbekistan. Acta Palaeontol Polonica 44(1): 71-81.

21. Gabunia LK, Sheveryeva NS, Gabunia VD (1990) A new opossum (Didelphidae, Marsupialia, Metatheria, Mammalia) from the base of the Oligocene of the Zaisan Depression (East Kazakhstan). Paleontologiceskij zurnal 1: 101-109.

22. Ducrocq S, Buffetaut E, Tong HB, Jaeger J, Jongkanjanasasoontorn J, et al. (1992) First fossil marsupial from south Asia. Journal of Vertebrate Paleontology 12(3): 395-399.
23. Wilson GP, Ekdale EG, Hoganson JW, Calede JJ, Linden AV (2016) A large carnivorous mammal from the Late Cretaceous and the North American origin of marsupials. Nat Commun 7: 13734.

24. Krause DW (2001) Fossil molar from a Madagascar marsupial. Nature 412(6846): 497-498.

25. Beck R (2013) Marsupial links to AS and Africa.

26. Bajpai S, Kapur VV, Thewissen JGM, Tiwari BN, Das DP (2005) First fossil marsupials from India: early Eocene Indodelphis n. gen. and Jaegeria n. gen. from Vastan lignite mine, District Surat, Gujarat. J Palaeontol Soc India 50(1): 147-151.

27. Paula Couto P (1961) Marsupiais fósseis do Paleoceno do Brasil. An Acad Brasileira de Ciências 33: 321-333.

28. Woodburne MO, Zinsmeister WJ (1982) Fossil land mammal from antarctica. Science 218(4569): 284-286.

29. Beck RM, Godthelp H, Weisbecker V, Archer M, Hand SJ (2008) Australia's oldest marsupial fossils and their biogeographical implications. PLos One 3(3): e1858.

\section{Your next submission with Juniper Publishers will reach you the below assets}

- Quality Editorial service

- Swift Peer Review

- Reprints availability

- E-prints Service

- Manuscript Podcast for convenient understanding

- Global attainment for your research

- Manuscript accessibility in different formats

( Pdf, E-pub, Full Text, Audio)

- Unceasing customer service

Track the below URL for one-step submission https://juniperpublishers.com/online-submission.php 